\title{
Struggle Form of Malay Women in Education in Chan-Pi Story of Love the Melayu by Berlian Santosa
}

\author{
Sri Yanti ${ }^{1}{ }^{*}$ Yenni Hayati $^{1}$ \\ ${ }^{1}$ Indonesian Language Department, Universitas Negeri Padang, Padang, Indonesia \\ "Corresponding author. E-mail:sriii2601@gmail.com
}

\begin{abstract}
This research is entitled The Struggle of Malay Women in Education in the Chan-Pi Hikayat Cinta Negeri Melayu Novel by Berlian Santosa. in the study of the relationship of literature with reality. This study seeks to analyze the forms of struggle of Malay women in education contained in the novel Chan-Pi saga Cinta Negeri Melayu. The stories studied were taken as samples with the consideration of representing the background of the struggle of Malay women in education. The results showed there were 13 data or quotes in the study and all data included in the form or form of the struggle of Malay women, namely the Rakai character. Based on the overall discussion carried out in the analysis section, It can be concluded that the novel Chan-Pi Hikaat Cinta Negeri Melayu describes how the figure of Takai, a Malay woman, struggles for education, even though she is only a babu or slave in a ship's port. Do not change his intention and determination to achieve his education and go in search of knowledge to people who are high in knowledge.
\end{abstract}

Keywords: Women's Struggle, Education, Sastra

\section{PRELIMINARY}

Literary work is a type of writing that contains aesthetic values and moral messages. Literary works contain a variety of knowledge and insights that are presented in the form of language art. Through artistic writings, readers can interpret them according to their own intuition and experience. That way, the assessment of each reader will be different [1]. Literary works are written by the author as a place to convey his emotions for the experiences he feels in everyday life.

The relationship between literature and society is interrelated. Both have an influence on attitudes, thought patterns, and actions. Literary works affect society and society also affects literary works. One of the literary works that is easily found is the novel.

According to Sudjiman [2], the novel is a form of literary work that contains the stories of the characters and the events they experienced with presentations according to the background of the story. The novel contains imaginative stories that tell in depth human life presented in good language. The benefits of the novel are not only as a means of entertainment, but also as a form of written art that discusses the values of life. The value of life displayed in the novel can be positive or negative. One of the goals of the novel is to give direction to the reader about good behavior and character.
Novel authors try to convey the stories of the characters through writings to change the mindset of the reader so that they can examine the good and bad of the object written. The story contains advice or messages to the reader so that the reader can take lessons that may or may not be imitated. Setiadi [3] said that the benefits of literary works are not only as a medium of entertainment to be enjoyed, but also as a reflection of life to be used as selfevaluation.

In the novel, the reader can also find a value system that is useful in social life. The value system contains the order of positive and negative values. The goal is that readers can imitate or stay away from the values contained in it [4]. The themes of literary works contained in the novels, among others, are the themes of education, religion, love, and so on.

In this study, the researcher uses a novel about the struggle of women, namely a novel entitled Chan-pi, a novel that tells the lives of Malay women. This novel is the work of Berlian Santosa.

Novels with the theme of women's struggles are a very good type of novel to study. Women are depicted as warriors who have to sacrifice sweat, blood, lamentation, ideals to be able to enjoy education. Women are also part of the less educated and poor third world. Therefore, in literary works (novels), women must fight for their lives to get a better fate [1]

In literary works, the marginalization that occurs in women occurs because of patriarchal understanding. This 
understanding of patriarchy makes women not get justice, especially for women in minority groups, such as racial, religious, class and ethnic groupings. As a result, women become the lowest layer of social life. The oppression of women can be carried out by men or by women themselves [5].

This research is based on the struggle of women who fight for education. This research is evidence and a tangible manifestation of the efforts of women who fight for education.

The purpose of this study is to add insight and research on the sociology of literature. This research is also an additional reference for other researchers regarding the study of written literature, especially novels. The formulation of the problem in this study is: how is the form of the struggle of Malay women in education in the novel chan-pi saga Cinta Melayu by Berlian Santosa.

This novel contains the value of women's struggles in education, the main female character in the novel chan-pi saga of love for the Malay country, tells the story of a woman who was once just a slave and becomes a woman who is highly educated and respected by many people.

\section{RESEARCH METHODS}

The method is a series of stages in research that are useful for finding out how a science works. the research method used must be in accordance with the object of research [6]. In this research, the method chosen is analytical and descriptive method. The analytical method is a research method to divide objects into ideas, meanings, structures, and processes. The analytical and descriptive methods were chosen because they can describe the problem accurately and in detail [1].

The steps taken in this data analysis method are to identify the data and then describe it. The process of analyzing the data was carried out based on the existing theory. The following are the stages of data analysis of this research. First, the researcher collects the forms of struggle carried out by the main character in the novel Chan-pi Hikayat Cinta Negeri Melayu.

Second, the researcher analyzes the reaction of the main character in fighting for education through dialogue, ideas, and events in the story. In this stage, the researcher also looks at the attitudes and responses of the main characters to social problems that occur in their environment.

\section{RESULTS AND DISCUSSION}

Chan-Pi novel is a novel set in Malay culture in the 11th century to the 13th century AD. The main character is told as a woman who has high ideals. This novel is decorated with a romance between the main character, a woman named Rakai and a man named Tsampa.

Rakai is a servant and coolie who has a high enthusiasm for learning. He has aspirations and hopes to be able to study at the Mo-Lo-Yeu Sanghrama majoring in medicine. on the other hand, a man named Tsampa had a job as a wealthy merchant. Tsampa studied at the college that Rakai coveted, but in different majors. Tsampa chose a literature major.

Mo-Lo-Yeu College is very famous and is often a stopover for Chinese and Hindustani students or monks. The existence of Rakai and Tsampa figures as Muslim youths is quite a minority at the university. Although often visited by Hindus and minorities, Tsampa and Rakai still adhere to Islam. In fact, these two figures are one of the reasons for the growing development of Islam around the Mo-Lo-Yeu College.

\subsection{Literary Sociology}

The literary work written by the author is motivated by the social conditions of the community that occur around the author. According to Teeuw \& Pradobo in, literary works and society are two inseparable components. Literary works can influence and be influenced by the social conditions of society. That way, literary works are not born from a cultural vacuum or pure imagination. The science of language and literature that discusses the relationship between literary works and the social life of society is the sociology of literature. Sociology of literature is defined as a way of analyzing literary works according to social theories. The community can be an object in a literary work or just an external reason [7].

\subsection{The Relationship of Literature with Reality}

Literature contains various thoughts of writing artists that revolve around social problems. Literature is considered to have mimetic properties. The events that are told in literary works describe the reality that occurs in society. The place, time, and atmosphere that occurs can also be known by humans. The filling elements of literary works must be suitable and in accordance with human experience in general [8].

The most powerful element forming literary works is language. Language determines the interaction between readers and writers. The language used in literary works must be able to represent the understanding of the readers and part of everyday life. The goal is to make literary works easy to understand [8].

Literary works become a direct reflection of the social system, family relationships, social levels of society, and so on. The author does not create characters, themes, language styles, and other elements by imagination. The 
author gets all the inspiration from human social life. Therefore, literary works are also called works of social reality [9].

\subsection{Education}

Education is a human effort to improve culture. Education cannot be separated from the development of human life [10]. Education and human life are two things that cannot be separated. Culture creates and is created by education. The past, present, and future are directly affected by the level of education of the community. A strong society has a high education and culture. Through education, people can create various solutions to life's problems.

Therefore, education cannot be left behind and separated from human civilization. Through education, humans can instill important values in order to create an atmosphere and order of civilized life in the future. In Law Number 20 of 2003 concerning the National Education System, education has the function of forming and developing the character of the nation. Education is expected to educate the younger generation so that the younger generation has good potential for religion and the state. Education can also create positive characters in children so that children become moral, knowledgeable, capable, healthy, independent, creative, and responsible [11].

Based on the explanations above, the results of this study are the form of women's struggle in education in the Chan-pi novel Hikayat Cinta Negeri Melayu. In the novel, Chan-pi, Hikayat Cinta Negeri Melayu, he describes the form of women's struggle in education for Rakai. She is a woman who has courage and enthusiasm even though there are risks in every path taken in finding the fruit of knowledge and the Rakai character is also a woman who always wants to know new things.

Rakai is a babu in a port and the place is called Zabaq, in zabqlah Rakai begins to study and seek knowledge even though he is only a babu. Babu on board cannot leave without permission from his superiors or boss but Rakai often steals opportunities and leaves the ship to meet his best friend in the market.

\section{Here's a quote:}

(1) People come to the zabaq a lot to reward them with the things they carry. But what attracted him was all things that contained writing because they were able to open the eyes of his heart and his mind soared into the sky, gaining meaning in it. page 20

In the quote (1) Rakai takes advantage of the gifts of people who come to the zabaq or people pay him with things that he thinks are interesting, not only the goods he receives but the goods that contain writing and Rakai is a woman who is eager to learn and wants to know knowledge that he did not know was attracted to him and after he read it, he felt his mind open or insightful about what he read.

(2) At every possible opportunity, Rakai often flees to meet another of his friends in the market, whom he thinks has more knowledge than himself, Tulaba. Although only a trader in the market, Tulaba's knowledge leapfrogged the area he experienced. page 20

In quote (2) after Rakai began to know the knowledge from the writings he got, and he felt that the knowledge was not right and needed to ask someone who knew more than himself. And he tries to meet his best friend even if it is secret only to meet his best friend named Tulaba, Tulaba is an old man who is called a walking knowledge book.

(3) "Teach me, O Lord Yeseer, the good-natured, ribbon Rakai Takzim. He bowed halfway and remained so until Mr. Yeseer asked to get up."

"You are studying with me, $\mathrm{O}$ woman who wants to kill her curiosity." A crescent smile stretched across the man's lips. page 21

In quote (3), the form of a woman who wants to learn about science and asks a great teacher to teach it by asking the teacher to be willing to teach it.

(4) "For Rakai, maybe humiliation is the highest place. But there is something higher than that: dreams"

It depicts the form of struggle on the female figure of Rakai when the sailor insults and considers himself low and it makes the sailor high in rank, but he says it may be humiliating to make you high but for me being tall is my dream even though I am insulted but not with the strength to achieve my dreams and aspirations.

(5) "I know Rakai. I saw another power in your realm of thought. But never mind, we're just losers, lackeys. It can't be more than that."

(6) Rakai shook his head. There were several palm trees swaying in the wind. He didn't agree. Don't lackeys have dreams too? Have a dream?" you're wrong friend" said Rakai looking at his best friend. "We are indeed born as slaves but are we willing to teach ourselves like this. Whoever it is, you as well as me, have the right to dream." page 25 
After reading the quote above, namely the quote (1)-(2), it describes the role of women who have a great desire to be able to rise from a life that used to be a slave to become a person who is respected by people, he also said to his best friend that we are all the same as slaves or not. We all have dreams that we must pursue.

(7) "You know, in Rakai's gentle demeanor there is a rock that is able to withstand the waves from breaking it into pieces. Rakai is not an ordinary woman," thought Met. His mind is not owned by slaves and other weak people who are resigned to fate."

He found a personal learner, a person who does not want to be blind to the usefulness of the universe, is always active in reading and curious. Met is sad, even he is not willing if Rakai is in this place forever. page 30

Quotation (7) the female character explains that the figure of Rakai is a woman who wants to know all things and she thinks that life cannot continue to run in place but we must bring change for the future,

(8) "I want to be like a star, soar in the sky to be a light in the dark night. Ah, the beauty of the light is also able to inject hopes and ideals. Is it wrong that I want to be like that?" asked Rakai suddenly

'I think it's too high for us Rakai'

"My best friend" Rakai said softly. "In fact, I want to raise my goals as high as the stars in the sky. If God wills, then nothing is impossible, we will be one of the stars, we will shine to illuminate the sky, illuminate the hopes of those who see it "Page 48

In (8) Like someone who is not capable, but has a big desire and wants to be a big person who can give knowledge to others. And that ideal is owned by everyone who has a great desire for knowledge, Rakai said in the quote is it wrong if people like us have high aspirations? And according to Rakai, it's not wrong because everyone has that goal, but it depends on the person's efforts and ways to achieve them. And Rakai also said that God determines everything and efforts and prayers will smooth the path we take to reach our goals and no matter how high those ideals are, if God wills, nothing is impossible.

(9) "I want to learn," said Rakai. Immediately, in the sky the stars nodded in agreement with their beautiful twinkles. "I can't wait, it feels like my steps are getting closer to my dream to study at the Mo-Lo-Yeu Sanghrama."

Rakai took a breath, his excitement swelled. "And now that the opportunity exists, I want to be a part of that college. Becoming a student there, as a way for me to fulfill my curiosity and thirst for knowledge" P 50

In the quote above, the figure of Rakai gets the opportunity to go to the college he has always dreamed of, namely the Mo-Lo-Yeu Sanghrama college. And he was very happy because he got the four even though he had Rakai and Met's efforts so that Rakai could arrive at the dungeon. As in the quote below

(10) "Patih Sipin, a kind-hearted servant once invited me to serve at Pari Palace. I met him at Zabaq"

How about Londering?" asked Met. "That human is going to lose one of his best cooks and obviously you can't just let him go unless" you hold your breath.. you run away" P 50

And in the quote (10) Met and Rakai are looking for a way for Rakai to get away from Londering skill which is their Boss there and Rakai is London's best chef. And Rakai said he would find a way by exchanging himself with gold jewelry, with the gold jewelry brought by Patih Sipin of course Lodering would think twice because by giving Rakai to Patih Sipin he could get gold jewelry. And met also suggested that he should just run away.

From the explanation above, it can be seen that the figure of Rakai struggles to leave the port and from the stress of his boss, Lodering, and achieves his dream of going to the Mo-Lo-Yeu Sanghrama college.

(11) "As far as I know, they are students who are studying. Not black magic like many savages learn. This is science. In fact they have devoted their whole life to Dram."

"Dharma?" asked Rakai. He was interested in what the Met just said, "What is that anyway? "At this point Raki thought, then it was as if there was a swish in his heart, "Science .. Darma .." He stared intently at Met's eyes and tried to ask for a definite answer to the syllables he had just heard. page 84

In quote (11) it is explained that Rakai is interested in what Met says about science but not black knowledge, and curious about the Darma meant by Met and is in his heart to know what Darma is. 
(12) Where is the place for them to study, O kind Tubala?" asked Rakai, more accurately confirming what Met said. Tulaba's hands, which had been engrossed in picking the rotten fish and then throwing them into the trash, stopped for a moment. Rakai stared. One original lifted. Like looking for something behind the five curious girls in front of him. Sincerity or hope. page 85

He couldn't understand it, it was really rare for a girl in Zabaq to have this kind of thinking. Instead of speaking from the mouths of noble daughters, but from the mouth of a female babu who is almost impossible to reveal the sweetness of the splendor of life. page 85

In the quote above (12) Tulaba did not think that Rakai's words were like that, because Tulba saluted what Rakai said, who was only a Malay woman, not from a noble woman and also only a babu.

(13) Met while wiping her meta corners that began to water said, "Go away, my friend!" Rakai felt his hands sweating "You're going to be one of the stars. Two things that go hand in hand. Rakai feels about to lose half his spirit. This is difficult but must be done. "I hope do PChan I get a friend as good as you, Met," he thought softly, "I will miss you always" he stammered. He couldn't afford to say goodbye.

Based on the quote above, a woman who is concerned with the future is drawn and she doesn't want to walk where she means that life must change even though now we can only dream but believe in effort and prayer and also in God's will while it is in goodness.

The sacrifice for the future made by the figure of Rakai because she is a woman who will have knowledge and actually also encourages her to always keep trying, and in the end they parted too it did not make Rakai discouraged to achieve his goals.

There are 13 data or quotes in the study and all data are included in the form or form of the struggle of the Malay woman, namely Rakai, in the Chan-Pi novel Rakai is a woman who is full of curiosity about science and has high aspirations to be able to study in the best college. Seeking knowledge wherever and whenever is not a problem for Rakai, it is clear that knowledge must be learned and learned from people who have more knowledge than himself. Women have the right to fight for their education because women are later to become mothers who are smart in managing the household, wise in making decisions.

For a woman, education is an important element so that women become strong and intelligent individuals.
Women will become figures who act as mothers for the next generation of the nation. Mothers who are knowledgeable and intelligent will educate children with the responsibility of their knowledge. Therefore, educating a woman is the same as educating the entire nation's next generation. Education makes it easy for mothers to distinguish between positive and negative things for their children. This education can minimize the occurrence of misunderstandings for children. One example is a mother who advises her child not to make mistakes in association [12].

Through education, mothers can maintain family health by providing quality and nutritious food. Education also indirectly creates a clean and healthy environment to improve the quality of life of the nation. In addition, education also makes the family have a wise view of life. Families can have the strength not to easily despair over the many problems they have.

Mudyahardjo [13] divides the notion of education into three ways, namely the very broad definition, the narrow definition, and the alternative or limited definition. In a very broad definition, education is life itself and lasts throughout life. This broad understanding is in line with what Henderson [14]. The narrow definition defines education as school, while in the alternative definition education is a conscious effort made by the family, community, and government, through lifelong guidance, teaching, and/or training activities in school and outside of school.

\section{CONCLUSION}

Based on the results of the analysis in the Chan-Pi novel about the form of Malay women's struggle, it was found 13 data and data such as data describing how the figure of a Malay woman Rakai figure fought for education and even though she was only a babu or slave in a port. Do not change his intention and determination to achieve his education and go in search of knowledge to people who are high in knowledge. Rakai is an image of a character that must be reflected because education for women is very important. And do not give up to gain knowledge despite the many obstacles and sacrifices.

\section{REFERENCES}

[1] S. P. Wibowo, "The Form of Women's Struggle in Education in the Anthology of Short Stories, A Thousand Dreams of Women in Buru, an Approach to 
Literary Sociology," Sanata Dharma University, Yogyakarta, 2008.

[2] P. Sudjiman, Stylistic Potpourri, Jakarta: Pustaka Jaya, 1998.

[3] E. M. Setiadi, Basic Social and Cultural Sciences, Jakarta: Kencana, 2006.

[4] R. D. Pradopo, Some Literary Theories, Methods, and Critics, Yogyakarta: Student Library, 2005.

[5] M. Hartiningsih, "Daughters Stolen by Tradition," Kompas.com, [Online]. Available: http://kompas.com/kompasprint/0602/11/Fokus/2426515.htm.

[6] K. S. Yudiono, Study Indonesian Literary Criticism, Bandung: Space, 1986.

[7] N. K. Ratna, Theory, Methods and Techniques of Literary Research, Yogyakarta: Learning Library, 2011.

[8] Teeuw, Literature and Literary Sciences, Introduction to Literary Theory, Jakarta: Pustaka Jaya, 1984.

[9] S. D. Damono, Sociology of Literature A Brief Introduction, Jakarta: Center for Language Development and Development of the Ministry of Education and Culture, 1979.

[10] A. N. Murniati, Indonesian Women in Religion, Culture, and Family Perspectives, Magelang: Indonesia Tera, 2004.

[11] Y. Sulistiani, "The Concept of Education for Women According to Dewi Sartika," Equalita Journal., 2020.

[12] J. Roudahtul, "he Nature of Women's Education and Career in the Perspective of Islamic Law," journal of UIN Alauddin Makassar, 2019.

[13] R. Mudyahardjo, Introduction to Education A Preliminary Study of the Basics of Education in General and Education in Indonesia, Jakarta: Rajawali Press, 2014.

[14] Sadulloh,U et al, Pedagogics, Bandung: Cipta Utama, 2007. 